Published in:

Gamito, S., 2008. Three main stressors acting on the Ria Formosa lagoonal system (Southern Portugal): Physical stress, organic matter pollution and the land-ocean gradient. Estuarine, Coastal and Shelf

Science 77, 710-720.

\title{
Three main stressors acting on the Ria Formosa lagoonal system (Southern Portugal): Physical stress, organic matter pollution and the land-ocean gradient
}

\author{
Sofia Gamito \\ IMAR, Faculdade de Ciências do Mar e do Ambiente, Universidade do Algarve, Campus de Gambelas, 8005-139 Faro, Portugal`
}

\begin{abstract}
During the last 15 years of the 20th century, several researchers carried out extensive sampling of benthic macrofauna communities in the Ria Formosa lagoon. The main objective of this paper is to discern the main communities of benthic fauna of the Ria Formosa and the leading stressors that limit them based on this large data set.

The high species richness and high diversity values observed at most of the stations or groups of stations indicate a good ecological status, with the exception of the sewage-impacted areas and the physically stressed areas. It was possible to define three main stressors acting on the Ria Formosa. The most important is the physical stress imposed by the limited water renewal in some areas of the Ria Formosa. The second is the nutrient and organic matter pollution that is limited to the vicinity of the sewage outfall stations and to some locations of the Ria Formosa. This is due to the dual effects of the low residence time of water, but also due to a degradation of water quality in places of relatively restricted water circulation but with high primary production, symptoms of eutrophication. The third stressor is the natural land-ocean gradient, denoting the influence of seawater exchanges and emersion time, attenuated by the high water exchange rates of Ria Formosa.

It was possible to differentiate the anthropogenic stress from the natural physical stress through the application of multivariate analysis. However, both structural (species richness and diversity indices) and functional indicators (trophic composition) indicate the same trend - low species richness, low diversity indices, and a community dominated by detritivores species at the locations characterized by high anthropogenic impact or by physical stress. The physically stressed areas were dominated by chironomid larvae and hydrobiid gastropods and the most polluted areas were dominated by oligochaetes, mainly tubificids.
\end{abstract}

Keywords: benthic invertebrates; distribution patterns; water renewal; eutrophication; physical stress; coastal lagoons

\section{Introduction}

Elliott (2002) considered that anthropogenic activity resulted in particular pressures in the marine ecosystems, such as the effects of bottom trawling, the discharge of cooling water from power stations or of sewage effluents. Recently, Dauvin (2007) designates as pressures particular environmental stressors, including direct pressures such as emissions. In fact, environmental stressors, either of natural origin or as a result of anthropogenic activity, can result in particular pressures in the ecosystem. Furthermore, some natural stressors can be modified by human intervention. For instance, physical stress due to high residence time can have a natural origin but its effects or pressure can be changed by anthropogenic activity such as the construction of a dam or the digging up of a channel to increase water circulation.

Coastal lagoons are usually among the marine habitats with the highest biological productivity (Alongi, 1998). As a consequence, lagoons play an important ecological role among the 
coastal zone ecosystems, providing a collection of habitat types for many species (Clark, 1998) and maintaining high levels of biological diversity. However, most lagoons are subjected to human exploitation through fishing, aquaculture, tourism, and urban, industrial and agricultural development, which induce changes that affect their ecology (Gamito et al., 2005).

Depending on their geomorphology and hydrology, these shallow coastal environments may be characterized by gradual or sharp daily and seasonal variations in physicalechemical water parameters. These variations are integrated by the benthic communities present in the coastal lagoons. Due to their limited mobility, benthic organisms can integrate environmental conditions over time better than pelagic organisms and are commonly used in the monitoring of anthropogenic impacts (Warwick et al., 1990) or the assessment of ecological patterns.

In a coastal lagoon several environmental gradients are expected to occur. The most important may be the landeocean gradient that is reflected in the sediment grain-size, with fine muddy or sandy mud particles on the land side and coarser sediments near the seaside (Quintino and Rodrigues, 1989). This results from the decreasing hydrodynamic energy as distance from the sea inlet increases. This landeocean gradient is also related with a salinity decrease towards the land side in lagoons with an important freshwater input, or an increase of salinity in lagoons with little freshwater input and important evaporation losses. Guelorget and Perthuisot (1984) call this landeocean gradient a "confinement" gradient. Gamito $(1997,2006)$ pointed out the importance of water renewal rate in semi-natural lagoons, which may be related with the landeocean gradient, with lower water renewal rates in the inner side of the lagoons, causing persistent physical stress. Another gradient in tidal lagoons is the intertidal/subtidal (and depth) gradient, with few species supporting long emersion periods. Other gradients might be resultant from anthropogenic activity, such as the release of urban and industrial sewage into the lagoons.

The Ria Formosa is a mesotidal shallow coastal lagoon, with five sand barrier inlands and six inlets, with a wet area of about $100 \mathrm{~km} 2$, including tidal channels $(29.5 \mathrm{~km} 2)$ and an extensive intertidal area constituted by salt marshes (32.1 km2), mud and muddy sand flats (10.1 km2), sandy sediments (14.2 km2) and macrophytes' beds (8.2 km2), according to aerial photographs from 1989 (Fidalgo, personal communication). The average depth relative to sea level is $2 \mathrm{~m}$ and the flooded surface in spring tides averages $84 \mathrm{~km} 2$ (Andrade et al., 2004). The tidal amplitude ranges from $3.3 \mathrm{~m}$ on spring tides to $1.0 \mathrm{~m}$ on neap tides, which causes important semidiurnal and fortnightly tidal amplitude variations, with an estimated average water residence time of 1.5 days (Saraiva et al., 2007). However, tidal flushing is not uniform throughout the lagoon and in the upstream locations it may not be well mixed, thereby increasing the residence time of water (Newton and Mudge, 2003; Tett et al., 2003). There are no major freshwater discharges in the western lagoon, where salinity ranges from 13 (due to episodic run-off that occurs from rainfall during winter) to 36.5 , and temperature from 12 to $27 \mathrm{C}$ (Newton and Mudge, 2003).

During the last 15 years of the 20th century, several large studies of benthic macrofauna communities were carried out in the western side of Ria Formosa. These studies had different objectives in view: Austen et al. (1989) sampled two possible gradients of sewage pollution; Calvário (personal communication) sampled a possible gradient of confinement and also four low intertidal stations,

representing the following biotopes: sand, muddy sands, sandy mud and Zostera bed; Gamito $(1997,2006)$ sampled four water reservoirs of salt pans (Salinas) and of a tidal mill, with different water renewal rates, and a fifth water reservoir, of a semi-intensive fish farm; Sprung (1994) sampled three intertidal stations, a Zostera noltii bed, a sand flat and a mudflat, with the main objective of determining the secondary production of these areas.

Based on the analysis of this large data set, the main objective of this paper was to describe the main communities of benthic fauna of the Ria Formosa and the leading stressors that explain or limit them.

\section{Methods}

A map with the approximate location of the sampling stations of the four research groups is presented in Fig. 1.

Gamito $(1997,2006)$ sampled two (sites C, D and E e stations $13 / 16,17 / 20$ and 21/22) or three stations (sites A and B e stations $1 / 6$ and $7 / 12$ ) in each water reservoir, depending on their size and shape. At each station, two cores of $0.01 \mathrm{~m} 2$ each were taken ( $2 \hat{A} 0.01 \mathrm{~m}_{2} 1 / 40.02 \mathrm{~m} 2$ ), and the sediment sieved with 1-mm mesh, except in the fifth reservoir, where four cores were taken (4 $\hat{A} 0.01 \mathrm{~m}_{2} 1 / 40.04 \mathrm{~m} 2$ ) at each station and a $0.5-\mathrm{mm}$ mesh sieve was used. Macrofauna was sampled for 2 years, every second month, at the first four sites, in 1985 and 1986. Site E was sampled from March 1996 to June 1997 every month. The water reservoirs were about 0.4- to 1-m deep, with deeper zones near the tidal gates. The fifth water reservoir was approximately $2-\mathrm{m}$ deep.

Austen et al. (1989) sampled 14 sandy mud stations on the lower intertidal (between MLWN and MLWS), seven stations on each of two transects, during summer 1987 and winter 1988. On transect A (stations 23e29), the sewage outfall drained almost immediately into the Faro channel, a large navigation channel connected to the Atlantic Ocean. At low tide, the sewage from the outfall on transect $C$ (stations $30 \mathrm{e} 36$ ) drained in an enclosed area of mudflat before it met the Faro channel and the rest of Ria Formosa at station 34. Five macrofauna samples were collected with either $10.3 \mathrm{~cm}$

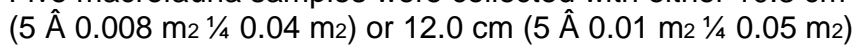
diameter cores, at each station, and sieved with $0.5-\mathrm{mm}$ mesh sieves. The organisms were identified to family level (see Austen et al., 1989, for details).

Calvário (personal communication) sampled six zones of the Faro channel (stations 37-73), from near the inlet to the city of Faro, in spring, summer, autumn and winter 1989. In each zone a transect was sampled, perpendicular to the main channel, with one station at the bottom of the channel and 


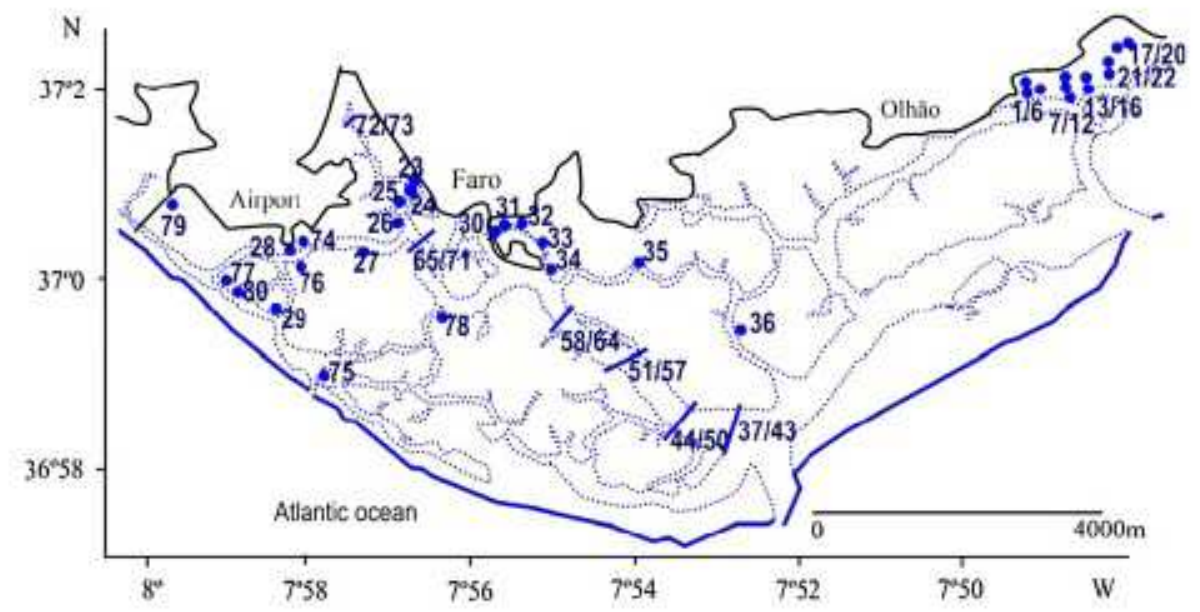

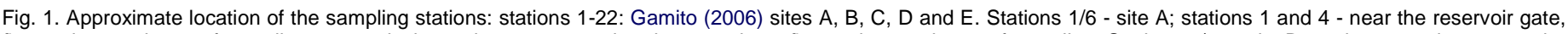

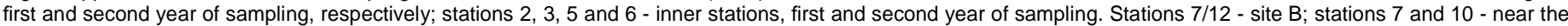

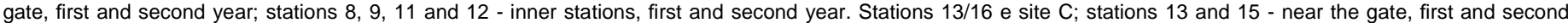

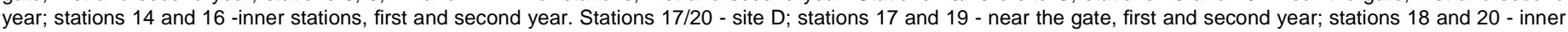

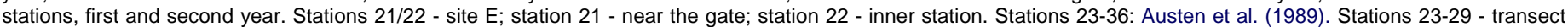

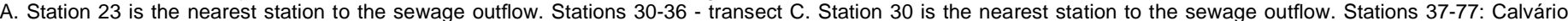

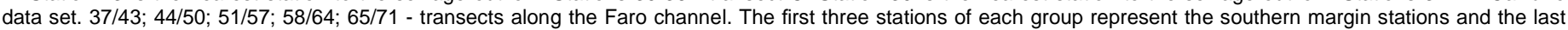

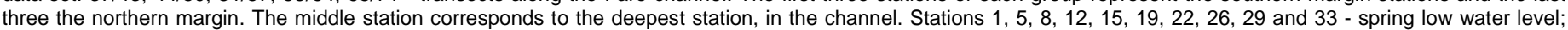

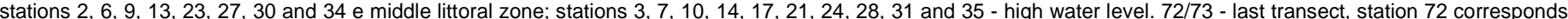

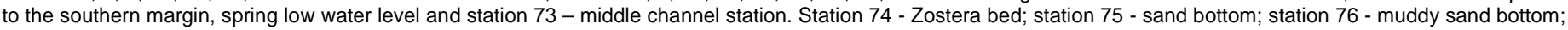
station 77 e sandy mud bottom. Stations 78/80: Sprung (1994). Station 78 - Zostera noltii bed; station 79 - mudflat; station 80 - sand flat.

three intertidal stations on either side of the channel; one station was situated high up in the intertidal zone (MHWS), another in the center (MTL) and the third close to the spring low water mark (MLWS). The innermost part the channel was only some decimeters deep at low tide and samples were taken from the bottom of the channel and at one site from the margin, which lead to 37 stations in total. In the intertidal zone, 15 cores were taken at each station, covering a total area of $0.3 \mathrm{~m}^{2}$. From the bottom of the channel six samples were taken using a van Veen grab, covering a total area of $0.3 \mathrm{~m}^{2}$. The sediment was sieved with $1-\mathrm{mm}$ mesh sieves. From January 1990 to January 1991, Calvário (personal communication) also sampled, every month, four common biotopes, in the Ria Formosa, near the spring low water level (MLWS), sand, sandy mud, muddy sand and Zostera bed, using the same methodology used for the intertidal stations (stations 74-77).

Sprung (1994) examined, every second month, 20 cores of $0.01 \mathrm{~m}^{2}$ each $\left(20 \times 0.01 \mathrm{~m}^{2}=0.2 \mathrm{~m}^{2}\right)$, at each station and sampling period, between July 1990 and October 1990, and four cores of $0.065 \mathrm{~m}^{2}$ each, from December 1990 until December 1991. The sediment was sieved with 1-mm mesh sieves (stations 78-80).

Previous studies showed that, for several multivariate methods, analyses based on two, three, four or five replicates produced the same main underlying gradients (Gamito and Rafaelli, 1992). However, due to the different sampling strategies and taxonomic identifying effort, the data were organized at family level and as relative densities, in percentage. Some mobile fauna such as fish, shrimps and mysids, and also small crustaceans such as ostracods were not considered in the global data matrix, since they were not sampled with the appropriate techniques. In a first step, the annual average family densities were determined, for each station of the four different teams, and then the relative densities determined. The data referent to a winter and a summer situation were also analyzed as well as a reduced data set considering the families with the higher total relative abundances. The main data patterns were analyzed by using the following ordination techniques: Multidimensional Scaling with PRIMER software, version 5.2, and Correspondence Analysis with CANOCO software, version 4.5. No further transformation of the data was preformed, as the data were already transformed in "relative densities in percentage".

Some stations or groups of stations were considered for further analysis at species level: the data from the deepest stations of the Calvário data set (stations 40, 47 and 54) were assembled, but the stations representing the different sediment types were kept separate (stations 74-77). Stations from each sampling site of Gamito data set were also assembled. The results from previous analyses showed that the differences among the sites were much larger than the differences among the stations of each site (Gamito, 2006).

For these stations or groups of stations, the total species richness was determined. The average values of species richness, density and Shannon-Wiener diversity and evenness were also determined. The results were presented with the deepest stations group in first place and the other stations or group of stations ordered by decreasing species richness. Differences in number of species due to different sampling effort 
were avoided since the stations with low sampling effort were grouped and the total sampled area considered. Only stations where the sediment was sieved with $1-\mathrm{mm}$ mesh were considered.

The relative abundance of the main trophic groups was also estimated for these stations or groups of stations and for three other stations or groups of stations. To assign the trophic group of each species a detailed literature research was carried out (see Appendix). When no information was obtained, the genera or even the family level was considered. The following trophic groups were considered e suspension feeders (plankton and detritus); deposit feeder (detritus and microphytobenthos); suspension/deposit feeders (species which have the two feeding modes depending on food availability) and herbivorous (macroalgae and macrophytes). The carnivorous, parasites, omnivorous and scavengers were grouped all together, following Valentine et al. (2002). In fact, most carnivores are also omnivores and scavengers, frequently being included in the same trophic group (see, for instance, Word, 1978 and Dauvin et al., 2007.

Finally, all species data from Calvário, Gamito and Sprung were aggregated, together with some Austen data set families, to give an overall idea of the species diversity of macrobenthic species from the Ria Formosa. All fish species were excluded from the data matrix, as well as some other taxonomic groups such as ostracods, since they were not captured with the appropriate techniques. All species and families' names were up dated according to Costello et al. (2004).

\section{Results}

The total number of macrobenthic taxa reported to Ria Formosa by Austen, Calvário, Gamito and Sprung was high - 328 taxa (Appendix). The total species richness was high in the deep channel stations of Calvario (94 species). However, the density was very low when compared to the other sites sampled, about 377 individuals $\mathrm{m}^{2}$ as well as the average species richness, but average diversity attains the highest value $(S=30 ; H=4.0 ; j=0.82$ ) (Fig. 2). Species richness reaches its maximum in the Zostera bed (station 74), with 130 taxa. The lowest value was found in group stations $1 / 6$, with only 22 taxa. However, the lowest richness must have occurred in station 30, where Austen et al. (personal communication) only found Tubificid oligochaetes and Talitrid amphipods, during the summer sampling and no individuals during the winter sampling.

The highest densities were found by Calvário at the Zostera bed (station 74), with an average density of $12.7 \times 10^{3}$ individuals $\mathrm{m}^{2}$ and by Gamito at stations $1 / 6$ with $11.4 \times 10^{3}$ individuals $\mathrm{m}^{2}$ (Fig. 2). Although with comparable densities, all the other indicators were different. The Zostera bed presented a higher average species richness and diversity $(S=62$; $H^{\prime}=3.9$ bits; $j=0.66$ ) while stations $1 / 6$ presented a lower average species richness and diversity $\left(S=9 ; H^{\prime}=1.8\right.$ bits; $i=0.59$ ).

Although with low density of benthic organisms the deep channel stations presented a relative balance of the main feeding groups, with a high proportion of the carnivores/scavengers group (Fig. 3A). The importance of the detritivores group increased towards the stations with macrophytes, decreased in the sandy and sandy mud stations and increased again in the more stressed locations, such as stations 1/6, exposed to high physical stress due to low water renewal rates and in the polluted stations, 23 and 30 . At this last station, only detritivores were found, but at low densities $\left(2 \times 10^{3}\right.$ individuals $\mathrm{m}^{2}$ during the summer sampling, no individuals during the winter sampling). Feeding diversity decreases towards the stations or groups of stations dominated by detritivores (Fig. 3B).

Although some taxonomic groups were not identified to the family level, such as Ascidea, Cnidaria, Echinoidea, Holothuroidea, Insecta, Nemertina, Polyplacophora, Oligochaeta, Opistobranchia and Sipuncula, the compilation of all data resulted in a matrix of 118 different taxa, reflecting again the high diversity of benthic invertebrates in the Ria Formosa.

The distribution of the stations in the MDS plot was not clear (not shown), and the stress value was high (0.18), indicating that no much reliance should be placed on this ordination (Clarke, 1993). Nevertheless, stations from the seaside of the channel transects (Calvário sampling) are seen in the left side of the plot and stations from the physically stressed environment (Gamito - site A) and polluted environment (Austen et al. - transect $C$ ) are seen in the right side.

In the Correspondence Analysis plot (Fig. 4A) a clear separation between physically stressed and polluted stations is shown. Axis 1 apparently separates stations subjected to physical stress (right side of axis 1) from all other stations. Axis 2 separates stations from polluted sites (positive side of the axis) from all other stations. The negative side of both axes separates the deeper stations of the main Ria Formosa channel, the Faro channel.

A close look to what happens in axes 1 and 3 (Fig. 4B) allows distinguishing in the left side of axis 1 the separation of main channel transect stations along axis 3 , the deeper stations and the intertidal stations of the first two Calvário transects in the negative side and the land side stations in the positive side of axis 3 , denoting a third gradient e seaside stations separated from land side stations. Separation of pollution gradient from this last sea-land gradient is only possible by examining axes 2 and 3 (Fig. 4C).

MDS ordinations carried out with winter and summer data gave high stress values ( 0.23 and 0.21 , respectively), and consequently the plots are not shown. With Correspondence Analysis, the same general patterns as previously described are seen in axes 1 and 2 (Fig. 4D, E), and in axes 1 and 3, and in 2 and 3 (not shown). However, there were some small changes from the previous analysis with the global data matrix. Only stations 1-6 (Gamito sampling) are projected in the right side of axis 1 , in the winter situation. Stations from transect $C$ of Austen et al. had either any living invertebrate at time of sampling (stations 30, 32 and 33) or were projected near the positive side of axis 2 . In summer, most of the stations of this transect $\mathrm{C}$ were projected near the right side of axis 1 , close to stations of the physically stressed site A (stations 1-6), due to the high abundance of gastropods of the family Hydrobiidae. The stations 15 and 20 were projected along the negative side of 

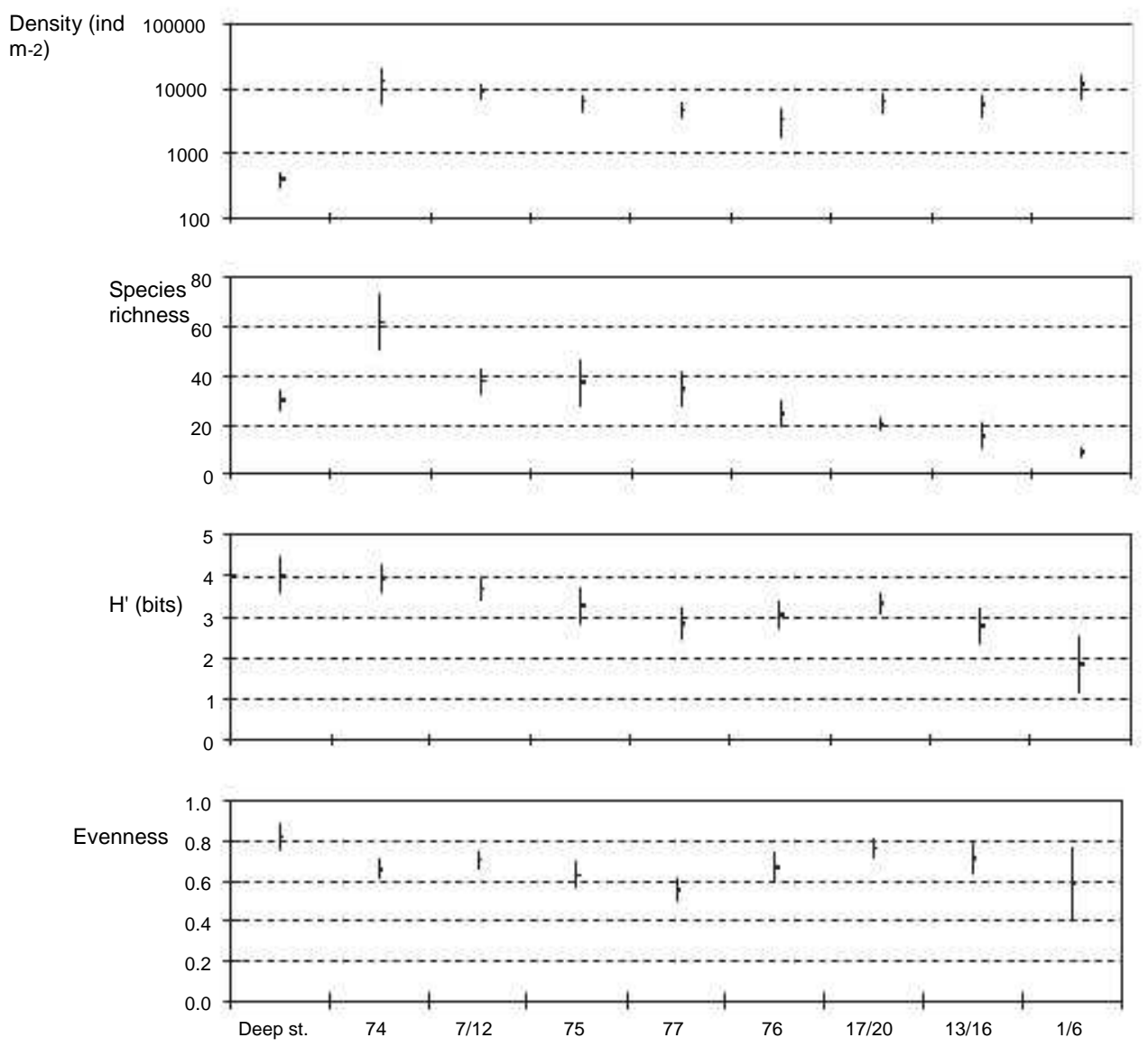

Fig. 2. Average and standard deviation of: density (individuals mÀ2); species richness; Ho e ShannoneWiener (bits) diversity index; j e evenness, observed in some groups of stations: Deep st - deep channel stations (stations 40, 47 and 54), the other codes are the same as in Fig. 1.

axis 2 , related with the polluted gradient. In fact, these stations were previously related with an eutrophication gradient (Gamito, 1997, 2006). Station 29 also was projected in the same side.

The percentage of variance explained by the different analyses was low, less than $30 \%$ considering the first three axes, but the data sets are very large, with more than 100 families. This implies reducing the information of a multidimensional space of more than 100 dimensions into a space of three dimensions. Reducing the dimensionality, by selection of a subset of data with fewer families, reduces the multidimensional space and may increase the variance explained by the first three axes. In fact, using a subset of data with the 21 families with higher total relative abundance, which corresponds to more than $80 \%$ of the total information, produced similar plots and increased the variance explained by the three axes to $42.3 \%$. Furthermore, other important gradients are expected to exist, at higher dimensions, such as the tidal level or the sediment type. However, the software used does not allow analyzing families' and stations' projections at higher dimensions.

The different mesh size sieves used by the teams do not seem to affect the multivariate analyses results. In fact, most of the Austin's transect stations were projected near stations from other teams, except the more impacted ones. Also stations from Gamito site $E$ were not separated from the other stations with similar ecological characteristics. Perhaps at higher dimensions, the mesh size might explain another gradient. Correspondence Analyses performed only with Calvário, Gamito (without site E stations) and Sprung data gave similar results but with an inversion of the second and third gradients. In fact, none of the three teams worked with a "putative" pollution gradient. Gamito (2006) identified an eutrophication gradient, due to a deterioration of water quality, during the second year of sampling, in some stations of sites C and D. In the results from the analyses with all the data, these stations were projected in the same direction of the more impacted stations of the pollution gradient. Without this "putative" gradient the pollution/eutrophication gradient was the third in importance, being the physical stress the most important, followed by the land-ocean gradient.

The families Hydrobiidae (gastropods), Capitellidae (polychaetes) and Semelidae (bivalves) were the most abundant families in all stations, representing almost $42 \%$ of all individuals sampled. The family Hydrobiidae was present only in 38 of the 80 stations, but when it was present it could reach high densities, the highest $\left(13.4 \times 10^{3}\right.$ individuals $\left.\mathrm{m}^{2}\right)$ was found in station 4. The family Capitellidae (4 species, see Appendix) was present in almost all stations (78 out of 80 ). The family Semelidae (5 species) was present in 67 of the 80 stations. These last two families were projected near the origin of the axes, meaning that they represent the Ria Formosa but no specific gradient (Fig. 5). 

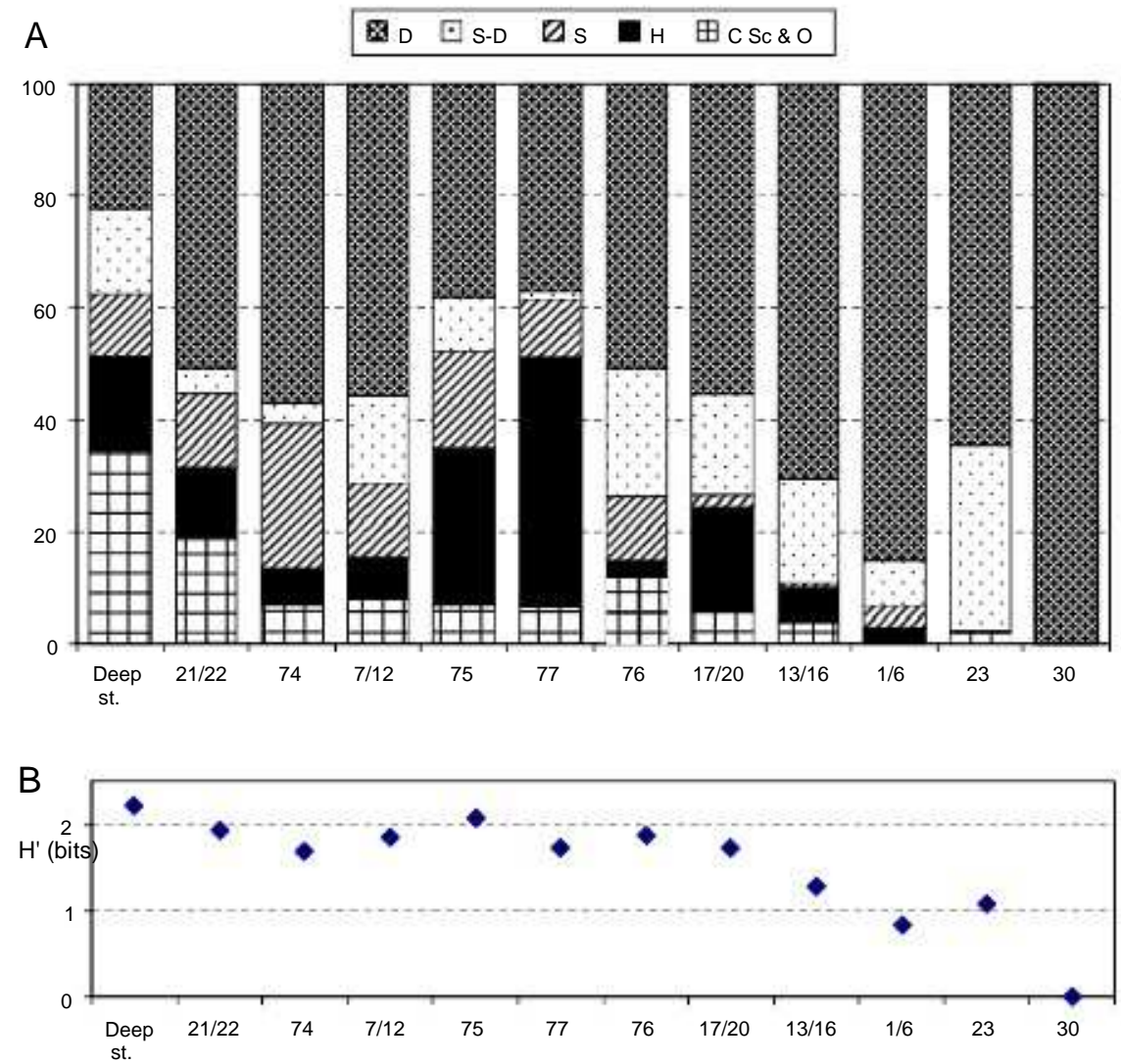

Fig. 3. (A): Main feeding groups in each of the group of stations considered in Fig. 2 and also in site $E$ - stations $21 / 22$ (Gamito data set) and stations A0 and $\mathrm{CO}$ stations 23 and 30 (Austin et al. data set). D - deposit feeders; S-D - suspension/deposit feeders; S - suspension feeders; H - herbivorous; C, Sc and O carnivorous, scavengers and omnivorous; (B): feeding diversity in the various stations or groups of stations considered.

The Hydrobiidae, together with Insecta (mostly Chironomus $\mathrm{sp}$. larvae), were projected near the positive side of axis 1, associated with the physical stressed gradient. Associated with the polluted section were the Oligochaeta, several amphipod families (Ampithoidae, Haustoriidae and Talitridae) and the isopod family Cirolanidae. The Cirolanidae and Haustoriidae were only reported by Austen et al. (personal communication).

Present in more than 50 stations out of 80 were the bivalves Cardiidae and Veneridae, the gastropods Cerithiidae and Nassariidae, the polychaetes Glyceridae, Nereididae, Nephtyidae and Spionidae, the amphipods Aoridae and Corophiidae and the Phylum Phoronida. These families, together with the families Capitellidae and Semelidae, represent the dominant invertebrate benthic fauna of Ria Formosa.

\section{Discussion}

The total number of macrobenthic species reported to Ria Formosa by Calvario, Gamito and Sprung was high - 328 taxa (Appendix), comparable to the vast Italian lagoon of Venice, with 356 macroinvertebrate taxa (Sabetta et al., 2007). The same authors reported to Grado Marano and Valli di Cornacchio, lagoons comparable in size to Ria Formosa, only 154 and 183 taxa, respectively. Bazairi et al. (2005) reported 147 taxa to a smaller Moroccan lagoon. In some Greek brackishwater lagoons the maximum number of invertebrate taxa was
84 (Reizopoulou and Nicolaidou, 2004), and in southern France the total number of zoobenthos in the less eutrophicated lagoon was only 24 (Mouillot et al. (2005). In Portugal, taxa richness was 268 in Santo André lagoon (da Fonseca et al., 1989) and 119 in Óbidos lagoon (Quintino et al., 1989).

Most of the taxa found in the Ria Formosa are characteristic of the Abra communities of estuaries and other sheltered regions (Thorson, 1957) or of the "biocenose lagunaire euryhaline and eurytherme" (Pérès and Picard, 1964). The dominant fauna consists of the bivalves Abra segmentum, Cerastoderma spp. and Loripes lacteus, the gastropods Bittium reticulatum and Cerithium vulgatum, the polychaetes Hediste diversicolor, Heteromastus filiformis and Streblospio spp., the crustaceans Apseudes latreillii, Corophium spp. and Microdeutopus spp., also common in Italian (Tagliapietra et al., 2000; Basset et al., 2006), French (Amanieu et al., 1978-1979) and in other Portuguese lagoons (Quintino and Rodrigues, 1989).

In the areas with low water renewal the bivalve Loripes lacteus is not present and the gastropod Hydrobia spp., the Chironomus insect larvae and the polychaete Capitella capitata dominate. In the more polluted areas all the faunas disappear, or only is represented by Oligochaetes and some amphipod families.

In the Ria Formosa several benthic habitats may be described: the tidal channels, the seagrass beds, the sandbanks and the mudflats. 

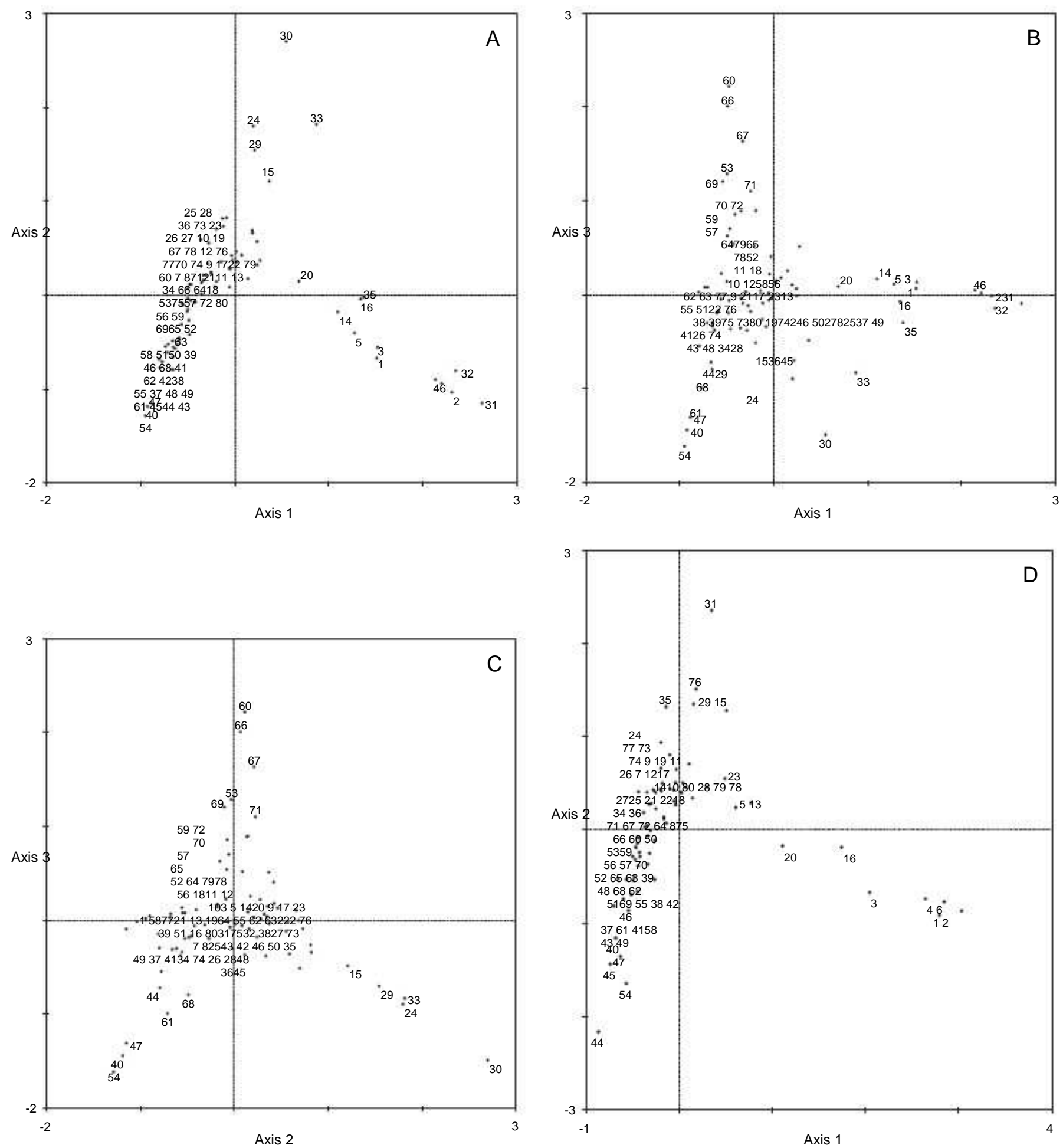

Fig. 4. (A): Correspondence Analysis carried out with 118 families and 80 stations. Projection of the stations in axes 1 and 2 . Percentage variance accounted for by axes: I = 12.3\%; I + II = 21.4\%; I + II + III =29.4\%. Station codes the same as in Fig. 1; (B): projection of the stations in axes 1 and 3 ; (C): projection of the stations in axes 2 and 3; (D): Correspondence Analysis carried out with 100 families and 77 stations e winter situation. Percentage variance accounted for by axes: $I=10.0 \% ; I+I I=17.9 \% ; I+I I+I I I=25.1 \% ;(E)$ : Correspondence Analysis carried out with 103 families and 80 stations - summer situation. Percentage variance accounted for by axes: I = 9.8\%; I II = 17.6\%; I III + III = 24.6\%.

A low density fauna can be found in the main tidal channel. This channel may be impacted due to the regular dredging to keep navigation possible and to feed the sand beaches from the ocean side of Ria Formosa, causing a low average density of macrofauna, but globally with a high diversity. The constant reworking of the sediment due to dredging may have released empty niches ready to be occupied by different species. The relative trophic balance found in this location may be artificial due to the instable sediment reflected in the variable communities found during the different sampling occasions. 


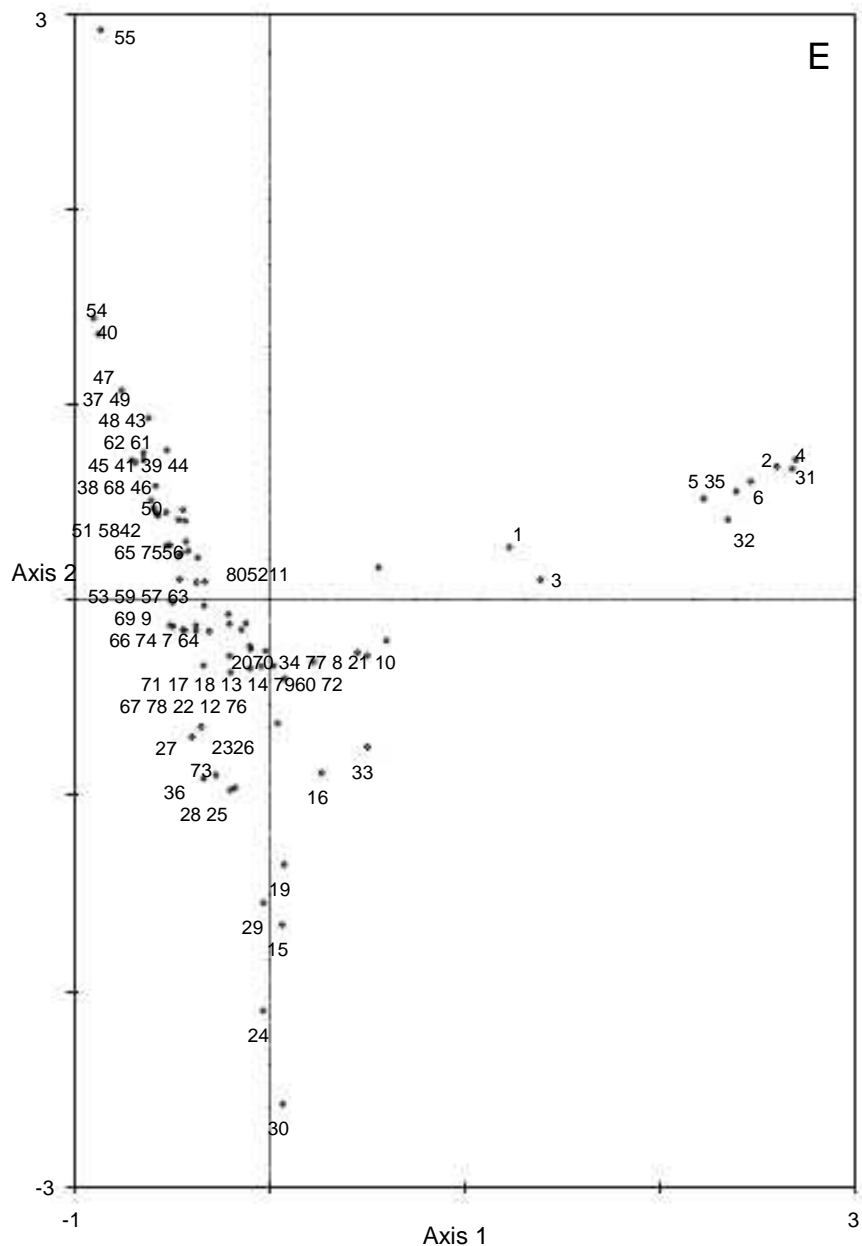

Fig. 4 (continued).

In the seagrass beds the trophic food web is dominated by detritivores, due to the large amounts of debris and organic matter that tend to accumulate as a consequence of a decrease in water circulation, but the other trophic groups were also well represented and the species richness attains its highest values. In the sandbanks the species richness is lower. The diversity decreases again towards the muddy sediments. In stressed zones, species richness decreases even more, and the benthic community may be dominated by a few and small group of resistant species, almost all detritivores.

The seagrasses, mainly Zostera noltii, may be considered as a keystone habitat-structuring seagrass species on intertidal mudflats (Hily and Bouteille, 1999; Diekmann et al., 2005). In fact, it was beneath this habitat where the highest species richness was found. Seagrass can contribute to the food web either directly through grazing on seagrass leaves or indirectly through grazing on the attached epiphytic algae (Heck and Valentine, 2006 and references therein). However, the food web is generally considered to be detrital-based (Cebrian et al., 1997; Vizzini et al., 2002). Sprung (1994) suggests that primary production within Ria Formosa is dominated by macrophytes and macroalgae, whilst planktonic production is mainly imported into the lagoon by tidal exchange. The seagrass detritus, together with salt marsh plant detritus, feeds the

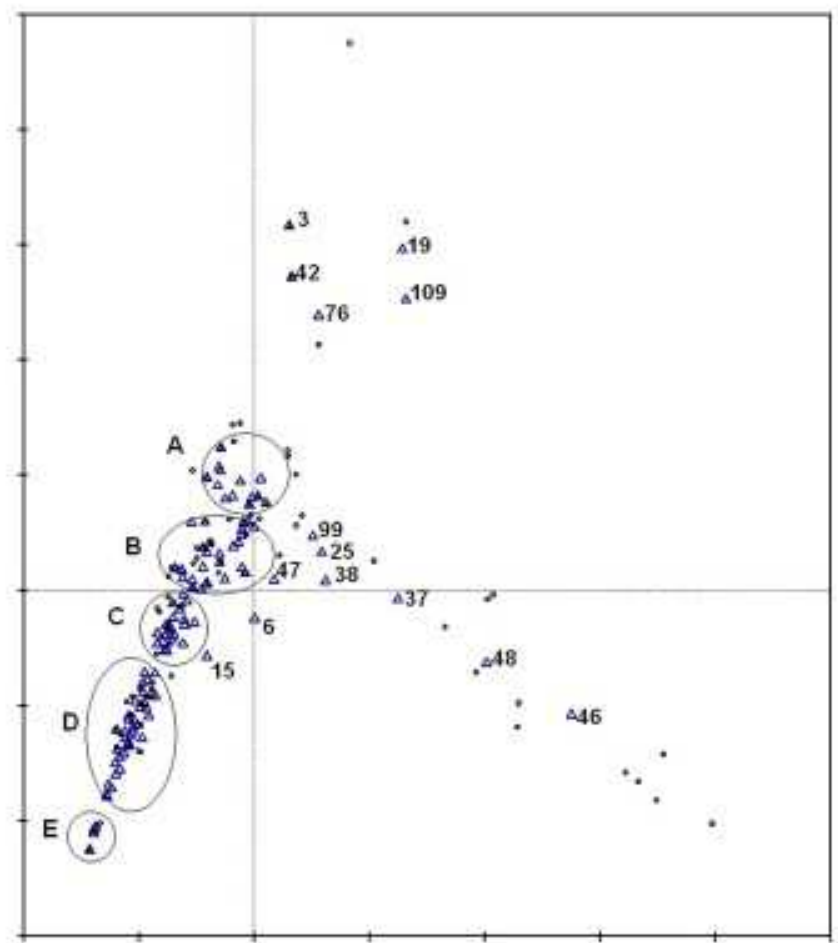

Fig. 5. Correspondence Analysis carried out with 118 families and 80 stations. Projection of the families and stations in axes 1 and 2 (To be analyzes together with Fig. $4 \mathrm{~A}$ ). Percentage variance accounted for by axes: $I=12.3 \%$; $I+I I=21.4 \% ; I+I I+I I I=29.4 \%$. Group A - families 2, 7, 11, 20, 35, $45,51,56,83,88,98,106$ and 105; group B - families 5, 9, 13, 14, 16 , $21,22,24,31,33,34,36,40,43,44,47,49,53,55,64,65,72,79,87,95$, $96,100,112,114$ and 115; group C - families 1, 8, 15, 39, 54, 58, 59, 63, $66,68,70,73,80,84,86,91,93,103,108,116$ and 118 ; group $D$ e families $4,10,12,17,18,23,27,28,32,41,50,52,57,60,61,62,67,69,71,74,75$, $77,78,81,82,85,90,92,97,101,102,104,107,110,111,113$ and 117; group E - families 26, 29, 30, 89 and 94. Families' codes: 1, Ampeliscidae; 2, Ampharetidae; 3, Ampithoidae; 4, Anomiidae; 5, Anthuridae; 6, Aoridae; 7, Aphroditidae; 8, Apseudidae; 9, Arcturidae; 10, ASCIDIA; 11, Callianassidae; 12, Calyptraeidae; 13, Capitellidae; 14, Caprellidae; 15, Cardiidae; 16, Cerithiidae; 17, Chaetopteridae; 18, CHORDATA; 19, Cirolanidae; 20, Cirratulidae; 21, CNIDARIA; 22, Conidae; 23, Corbulidae; 24, Corophiidae; 25, Cossuridae; 26, Cymothoidae; 27, Dexaminidae; 28, Diogenidae; 29, Donacidae; 30, Dorippidae; 31, Dorvilleidae; 32, ECHINOIDEA; 33, Epitoniidae; 34, Eunicidae; 35, Eusiridae; 36, Fasciolariidae; 37, Flabelligeridae; 38, Gammaridae; 39, Glyceridae; 40, Gnathiidae; 41, Goniadidae; 42, Haustoriidae; 43 , Hesionidae; 44, Holognathidae; 45, Holothuroidea; 46, Hydrobiidae; 47, Idoteidae; 48, INSECTA; 49, Iphimediidae; 50, Isaeidae; 51, Ischyroceridae; 52, Janiridae; 53, Kelliidae; 54, Lasaeidae; 55, Leptocheliidae; 56, Leptostraca; 57 , Leucothoidae; 58, Lucinidae; 59, Lumbrineridae; 60, Lysianassidae; 61, Mactridae; 62, Magelonidae; 63, Maldanidae; 64, Melitidae; 65, Montacutidae; 66, Muricidae; 67, Mytilidae; 68, Nassariidae; 69, Naticidae; 70, NEMERTINA; 71, Nephtyidae; 72, Nereididae; 73, Nuculidae; 74, Oedicerotidae; 75, OFIURIDEO; 76, OLIGOCHAETA; 77, Onuphidae; 78, Opheliidae;

79, OPISTOBRANCHIA; 80, Orbiniidae; 81, Oweniidae; 82, Paguridae; 83 , Paraonidae; 84, Pectinariidae; 85, Pholadidae; 86, PHORONIDA; 87, Phyllodocidae; 88, Pilumnidae; 89, Pisionidae; 90, Polynoidae; 91, POLYPLACO PHORA; 92, Pontoporeiidae; 93, Portunidae; 94, Psammobiidae; 95, Pyramidellidae; 96, Rissoidae; 97, Sabellariidae; 98, Sabellidae; 99, Semelidae; 100, Serpulidae; 101, Sigalionidae; 102, SIPUNCULA; 103, Solenidae; 104 Sphaeromatidae; 105, Spionidae; 106, Spirorbidae; 107, Stenothoidae; 108 Syllidae; 109 , Talitridae; 110 , Tanaidae; 111 , Tellinidae; 112 , Terebellidae; 113, Thraciidae; 114, Trochidae; 115, Turritellidae; 116, Upogebiidae; 117 , Urothoidae; 118 , Veneridae. 
adjacent areas, such as the sand and mudflats and the tidal channels. It is also exported to the ocean, with the tides.

However, seagrass habitat is degrading worldwide due to anthropogenic disturbances, such as mechanical damage (by dredging, fishing and anchoring), eutrophication, aquaculture development, coastal construction and climate change (Duarte, 2002). In the Ria Formosa, another important factor for seagrass loss is clam culture. The clam-beds are prepared by destroying the intertidal Zostera noltii meadows and covering the natural sediment with coarser terrestrial sediment (Duarte et al., 2004). Furthermore, natural muddy areas are disturbed due to the systematic collection of benthic organism such as mollusks, polychaetes and sipunculids, as bait for recreational fishing. Sandy areas used for clam farming are also periodically reworked by fishermen to collect clams and to promote oxygenation of deeper sediment layers (Falcão et al., 2006).a In fact, Austen et al. (1989) concluded that macrobenthos in winter appeared to respond to sewage enrichment only in the immediate vicinity of the sewage outfalls, but that $A B C$ plots indicated that macrobenthic communities were moderately stressed throughout the area in summer, possible due to human sediment digging for shellfish.

When the environmental conditions deteriorates there is a decrease of species richness, the food web becomes dominated by detritivores and the density of organisms may increase, in a first step, as was described by Pearson and Rosenberg (1978) for organically polluted sites, due to the development, in a low competitive environment, of fast growing small opportunistic species. If the environment deteriorates even more all organisms may die. In fact, Austen et al. (personal communication) hardly found any organism in the more sewage-impacted area of Ria Formosa. The same pattern of decreasing species diversity and increasing abundance of small opportunistic species was observed in the physically stressed stations, the local with low water renewal e site A (Gamito, 1997, 2006), due to extreme environmental conditions essentially revealed by large salinity variation.

In a recent work on two semi-intensive fish aquaculture reservoirs in the Ria Formosa with high organic matter loads, Carvalho et al. (2006) also found low ShannoneWiener diversity values, with most values varying between 1 and 2 bits. Dominant macroinvertebrate species composition was similar to the dominant fauna of site A. Apparently, it is hard to differentiate typical organisms characteristic of organic pollution from organisms indicators of physical natural stress. Most of them are considered opportunistic species, of low individual biomass but high grow rates and poor competitors, the so-called r-strategists (Pianka, 1970).

In the last years, some attempts were made in order to classify the ecological status of the Ria Formosa, but based only on water quality and macroalgae growth. Nobre et al. (2005) assessed the Ria Formosa eutrophication status as "good", on the Water Framework Directive scale (high, good, moderate, poor and bad). They concluded that the Ria Formosa has a short water residence time and eutrophication symptoms are not apparent in the water column. However, there are some eutrophication symptoms such as excessive episodic growth of macroalgae and strong dissolved oxygen fluctuations in tidal pools. Newton et al. (2003) classified the trophic state of the Ria Formosa based on nutrients data in the water column and in the sediment together with chlorophyll a and oxygen saturation in the water column. Ria Formosa was classified either in a poor to bad state or in a near pristine state, depending on the assessment method used.

Although no specific methodology was applied to define the ecological status of Ria Formosa based on benthic macrofauna, the high species richness and high diversity values observed in most of the stations or groups of stations point out to an elevated ecological status, with the exception of the more sewage-impacted areas and the physically stressed locals. In the delimitation of monitoring stations special care must be taken due to the spatial variability reflected in the different habitats. Also the regular dredging of the main tidal channels may affect the monitoring results.

It was possible to define three main stressors acting in Ria Formosa. Apparently, the most important is the physical stress imposed by low water renewal in some locations of Ria Formosa, detected previously by Gamito $(1997,2006)$. The second one is the pollution effect of sewage outfalls, limited to the vicinity of the outfall stations, due to the low residence time of water, as previously described by Austen et al. (1989) and Hubert et al. (2006), but also related to eutrophication accompanied by a degradation of water quality in places of relatively restricted water circulation with high primary production (Gamito, 1997, 2006). The third one and apparently less important, due to the high water exchange rates of Ria Formosa, is the landeocean gradient, denoting the influence of seawater exchanges and emersion time.

Recently, Elliott and Quintino (2007) suggested that estuarine faunal and floral community is adapted to and reflects high spatial and temporal variability in naturally highly stressed areas, but that their features are similar to those found in anthropogenically stressed areas. This makes it difficult to differentiate between the two stressors, the natural and the induced. Coastal lagoons are also considered naturally stressed environments but in the present study it was possible to differentiate the anthropogenic stress from the natural physical stress through the application of multivariate analysis. However, both structural (species richness and diversity indices) and functional indicators (trophic composition) indicate the same trend e low species richness, low diversity indices and a community dominated by small opportunistic detritivores species.

\section{Acknowledgments}

Special thanks are due to Dr. Alice Newton, for text revision and constructive comments. Dr. Donald S. McLusky and an anonymous referee greatly improved the manuscript.

\section{Appendix. Supplementary data}

Supplementary data associated with this article can be found, in the online version, at doi:10.1016/j.ecss.2007.11.013. 


\section{References}

Alongi, D.M., 1998. Coastal Ecosystem Processes. CRC Press, Boca Raton $419 \mathrm{pp}$.

Amanieu, M., Guelorget, O., Michel, P., 1978-1979. Évolution structurale de peuplements de la macrofaune benthique des étangs palavasiens. Vie et Milieu 28-29, 531-547.

Andrade, C., Freitas, M.C., Moreno, J., Craveiro, S.C., 2004. Stratigraphical evidence of Late Holocene barrier breaching and extreme storms in lagoonal sediments of Ria Formosa, Algarve, Portugal. Marine Geology 210, 339-362.

Austen, M.C., Warwick, R.M., Rosado, M.C., 1989. Meiobenthic and macrobenthic community structure along a putative pollution gradient in Southern Portugal. Marine Pollution Bulletin 20, 398-405.

Basset, A., Galuppo, N., Sabetta, L., 2006. Environmental heterogeneity and benthic macroinvertebrate guilds in Italian lagoons. Transitional Waters Bulletin 1, 48-63.

Bazairi, H., Bayed, A., Hily, C., 2005. Structure et bioevaluation de l'état écologique des communautes benthiques d'un écosystème lagunaire de la cote atlantique marocaine. Comptes Rendus Biologies 328, 977-990.

Carvalho, S., Barata, M., Pereira, F., Gaspar, M.B., da Fonseca, L.C., PousãoFerreira, P., 2006. Distribution patterns of macrobenthic species in relation to organic enrichment within aquaculture earthen ponds. Marine Pollution Bulletin 52, 1573-1584.

Cebrian, J., Duarte, C.M., Marba, N., Enriquez, S., 1997. Magnitude and fate of the production of four co-occurring western Mediterranean seagrass species. Marine Ecology Progress Series 155, 29-44.

Clark, J.R., 1998. Coastal Seas. The Conservation Challenge. Blackwell Science, Oxford, $134 \mathrm{pp}$.

Clarke, K.R., 1993. Non-parametric multivariate analyses of changes in community structure. Australian Journal of Ecology 18, 117-143.

Costello, M.J., Bouchet, P., Boxshall, G., Emblow, C., Vanden Berghe, E., 2004. European Register of Marine Species. Available from: http://www marbef.org/data/erms.php.

Dauvin, J.C., 2007. Paradox of estuarine quality: benthic indicators and indices, consensus or debate for the future. Marine Pollution Bulletin 55, 271-281.

Dauvin, J.C., Ruellet, T., Desroy, N., Janson, A.-L., 2007. The ecological quality status of the bay of Seine and Seine estuary: use of biotic indices. Marine Pollution Bulletin 55, 241-257.

Diekmann, O.E., Coyer, J.A., Ferreira, J., Olsen, J.L., Stam, W.T., Pearson, G.A., Serr o, E.A., 2005. Population genetics of Zostera noltii along the west lbe-a rian coast: consequences of small population size, habitat discontinuity and near-shore currents. Marine Ecology Progress Series 290, 89-96.

Duarte, C.M., 2002. The future of seagrass meadows. Environmental Conservation 29, 192-206.

Duarte, C.M., Marbá, N., Santos, R., 2004. What may cause loss of seagrasses? In: Borum, J., Duarte, C.M., Krause-Jensen, D., Greve, T.M. (Eds.), European Seagrasses: an Introduction to Monitoring and Management. The Monitoring and Managing of European Seagrass project, ISBN 87-89143-21-3, pp. 24-32. Available from: http://www.seagrass.org.

Elliott, M., 2002. The role of the DPSIR approach and conceptual models in marine environmental management: an example for offshore wind power. Marine Pollution Bulletin 44, iii-vii.

Elliott, M., Quintino, V., 2007. The estuarine quality paradox, environmental homeostasis and the difficulty of detecting anthropogenic stress in naturally stressed areas. Marine Pollution Bulletin 54, 640-645.

da Fonseca, L.C., Costa, A.M., Bernardo, J.M., 1989. Seasonal variation of benthic and fish communities in shallow land-locked coastal lagoon (St. André, SW Portugal). Scientia Marina 53, 663-669.

Falcão, M., Caetano, M., Serpa, D., Gaspar, M., Vale, C., 2006. Effects of in-a fauna harvesting on tidal flats of a coastal lagoon (Ria Formosa, Portugal): implications on phosphorus dynamics. Marine Environmental Research $61,136-148$

Gamito, S., 1997. Application of canonical correspondence analysis to environmental and benthic macrofauna data of four sites in the Ria Formosa (Portugal). Publicaciones Especiales Instituto Español de Oceanografia 23, 41-52.
Gamito, S., 2006. Benthic ecology of semi-natural coastal lagoons, in the Ria Formosa (Southern Portugal), exposed to different water renewal regimes. Hydrobiologia 555, 75-87.

Gamito, S., Rafaelli, D., 1992. The sensitivity of several ordination methods to sample replication in benthic surveys. Journal of Experimental Marine Biology and Ecology 164, 221-232.

Gamito, S., Gilabert, J., Marcos, C., Pérez-Ruzafa, A., 2005. Effects of changing environmental conditions on lagoon ecology. In: Gönenç, I.E., Wofflin, J. (Eds.), Coastal Lagoons. Ecosystem Processes and Modeling for Sustainable Use and Development. CRC Press, Boca Raton, pp. 193-229.

Guelorget, O., Perthuisot, J.P., 1984. Indicateurs biologiques et diagnose écologique dans le domaine paralique. Bulletin d'Ecologie 15, 67-76.

Heck Jr., K.L., Valentine, J.F., 2006. Planteherbivore interactions in seagrass meadows. Journal of Experimental Marine Biology and Ecology 330, 420-436.

Hily, C., Bouteille, M., 1999. Modifications of the specific diversity and feeding guilds in an intertidal sediment colonized by an eelgrass meadow (Zostera marina) (Brittany, France). Comptes Rendus de l'Academie des Sciences - Serie III, 322, 1121-1131.

Hubert, F., Pellaud, M., Gamito, S., 2006. Environmental effects of marine fish pond culture in the Ria Formosa (Southern Portugal). Hydrobiologia 555, 289-297.

Mouillot, D., Laune, J., Tomasini, J.-A., Aliaume, C., Brehmer, P., Dutrieux, E., Do Chi, T., 2005. Assessment of coastal lagoon quality with taxonomic diversity indices of fish, zoobenthos and macrophyte communities. Hydrobiologia 550, 121-130.

Newton, A., Mudge, S.M., 2003. Temperature and salinity regimes in a shallow, mesotidal lagoon, the Ria Formosa, Portugal. Estuarine, Coastal and Shelf Science 56, 1-13.

Newton, A., Icely, J.D., Falcão, M., Nobre, A., Nunes, J.P., Ferreira, J.G.,a Vale, C., 2003. Evaluation of eutrophication in the Ria Formosa coastal lagoon, Portugal. Continental Shelf Research 23, 1945-1961.

Nobre, A.M., Ferreira, J.G., Newton, A., Simas, T., Icely, J.D., Neves, R., 2005. Management of coastal eutrophication: integration of field data, ecosystem-scale simulations and screening models. Journal of Marine Systems 56, 375-390.

Pearson, T.H., Rosenberg, R., 1978. Macrobenthic succession in relation to or ganic enrichment and pollution of the marine environment. Oceanography Marine Biology: An Annual Review 16, 229-311.

Pérès, J.-M., Picard, J., 1964. Nouveau manuel de bionomie benthique de la Mer Mediterranee. Recueil des Travaux de la Station Marine d'Endoume 31, 1-137.

Pianka, E.R., 1970. On $r$ and K selection. American Naturalist 104, 592-597.

Quintino, V., Rodrigues, A.M., 1989. Environmental gradients and distribution of macrozoobenthos in three Portuguese coastal systems: Óbidos, Albufeira and Alvor. In: Ryland, J.S., Tyler, P.A. (Eds.), Reproduction, Genetics and Distribution of Marine Organisms, pp. 441-450. Fredensborg, Denmark

Quintino, V., Rodrigues, A.M., Gentil, F., 1989. Assessment of macrobenthic communities in the lagoon of Obidos, western coast of Portugal. Scientia Marina 53, 645-654.

Reizopoulou, S., Nicolaidou, A., 2004. Benthic diversity of coastal brackishwater lagoons in western Greece. Aquatic Conservation: Marine and Freshwater Ecosystems 14, S93-S102.

Sabetta, L., Barbone, E., Giardino, A., Galuppo, N., Basset, A., 2007. Speciesearea patterns of benthic macro-invertebrates in Italian lagoons. Hydrobiologia 577, 1573-5117.

Saraiva, S., Pina, P., Martins, F., Santos, M., Braunschweig, F., Neves, N., 2007. Modelling the influence of nutrient loads on Portuguese estuaries. Hydrobiologia 587, 5-18.

Sprung, M., 1994. Macrobenthic secondary production in the intertidal zone of the Ria Formosa e a lagoon in Southern Portugal. Estuarine, Coastal and Shelf Science 38, 539-558.

Tagliapietra, D., Pavan, M., Wagner, C., 2000. Benthic patterns in a salt marsh basin: a snapshot of Palude della Rosa (Venetian lagoon, Italy). Wetlands Ecology and Management 8, 287-292.

Tett, P., Gilpin, L., Svendsen, H., Erlandsson, C.P., Larsson, U., Kratzer, S., Fouilland, E., Janzen, C., Lee, J.-Y., Grenz, C., Newton, A., Ferreira, J.G., Fernandes, T., Scory, S., 2003. Eutrophication and some European waters of restricted change. Continental Shelf Research 23, 1635-1671. 
Thorson, G., 1957. Bottom communities (sublittoral or shallow shelf). In: Hedgpeth, J.W. (Ed.), Treatise on Marine Ecology and Paleocology I

Ecology. Geological Society of America, New York, pp. 461-534.

Valentine, J.W., Roy, K., Jablonski, D., 2002. Carnivore/non-carnivore ratios in northeastern Pacific marine gastropods. Marine Ecology Progress Series 228, 153-163.

Vizzini, S., Sara, G., Michener, R.H., Mazzola, A., 2002. The role and contribution of the seagrass Posidonia oceanica (L.) Delile organic matter for secondary consumers as revealed by carbon and nitrogen stable isotope analysis. Acta Oecologica 23, 277-285.

Warwick, R.M., Platt, H.M., Clarke, K.R., Agard, J., Gobin, J., 1990. Analysis of macrobenthic and meiobenthic community structure in relation to pollution and disturbance in Hamilton Harbour, Bermuda. Journal of Experimental Marine Biology and Ecology 138, 119-142.

Word, J., 1978. In: Bascom, W. (Ed.), The infaunal trophic index, pp. 19-39. Southern California Coastal Water Research Project. 